Article

\title{
Serpin Family E Member 1 Tag Single-Nucleotide Polymorphisms in Patients with Diabetic Nephropathy: An Association Study and Meta-Analysis Using a Genetic Model-Free Approach
}

\author{
Maria Tziastoudi ${ }^{1, *(D)}$, Efthimios Dardiotis ${ }^{2}{ }^{(D}$, Georgios Pissas ${ }^{1}$, Georgios Filippidis ${ }^{1}$, Spyridon Golfinopoulos ${ }^{1}$, \\ Vasileios Siokas $^{2}$, Sophia V. Tachmitzi ${ }^{3}$, Theodoros Eleftheriadis ${ }^{1}$, Georgios M. Hadjigeorgiou ${ }^{2,4}$, \\ Evangelia Tsironi ${ }^{3}$ and Ioannis Stefanidis ${ }^{1}$ \\ 1 Department of Nephrology, Faculty of Medicine, School of Health Sciences, University of Thessaly, \\ 41110 Larissa, Greece; gpissas@msn.com (G.P.); gfilippid@yahoo.gr (G.F.); spygolfin@yahoo.gr (S.G.); \\ telefteriadis@med.uth.gr (T.E.); stefanid@med.uth.gr (I.S.) \\ 2 Laboratory of Neurogenetics, Department of Neurology, University Hospital of Larissa, University of \\ Thessaly, 41110 Larissa, Greece; edar@med.uth.gr (E.D.); bill_s1983@hotmail.com (V.S.); \\ gmhadji@med.uth.gr (G.M.H.) \\ check for \\ updates \\ Citation: Tziastoudi, M.; Dardiotis, \\ E.; Pissas, G.; Filippidis, G.; \\ 3 Department of Ophthalmology, Faculty of Medicine, School of Health Sciences, University of Thessaly, \\ 41110 Larissa, Greece; sophitach@yahoo.gr (S.V.T.); etsiron@med.uth.gr (E.T.) \\ 4 Department of Neurology, Medical School, University of Cyprus, Nicosia 22006, Cyprus \\ * Correspondence: matziast@med.uth.gr; Tel.: +30-2413501667; Fax: +30-2413501015
}

Golfinopoulos, S.; Siokas, V.; Tachmitzi, S.V.; Eleftheriadis, T.; Hadjigeorgiou, G.M.; Tsironi, E.; et al. Serpin Family E Member 1 Tag Single-Nucleotide Polymorphisms in Patients with Diabetic Nephropathy: An Association Study and Meta-Analysis Using a Genetic Model-Free Approach. Genes 2021, 12, 1887. https://doi.org/10.3390/ genes12121887

Academic Editor: Maciej Wnuk

Received: 15 October 2021

Accepted: 23 November 2021

Published: 25 November 2021

Publisher's Note: MDPI stays neutral with regard to jurisdictional claims in published maps and institutional affiliations.

Copyright: (c) 2021 by the authors. Licensee MDPI, Basel, Switzerland. This article is an open access article distributed under the terms and conditions of the Creative Commons Attribution (CC BY) license (https:// creativecommons.org/licenses/by/ $4.0 /)$.

\begin{abstract}
Background: Many lines of evidence highlight the genetic contribution on the development of diabetic nephropathy (DN). One of the studied genes is SERPINE1 whose the role in the risk of developing DN remains questionable. In order to elucidate the contribution of SERPINE1 in DN progression in the context of type 2 diabetes mellitus (T2DM), we conducted an association study and meta-analysis of SERPINE1 genetic variants. Materials and Methods: A total of 190 patients with DN, 150 T2DM (type 2 diabetes mellitus) patients without DN and 238 healthy controls were recruited. We selected five tag single-nucleotide polymorphisms (SNPs) from the HapMap. The generalized odds ratio $\left(\mathrm{OR}_{\mathrm{G}}\right)$ was calculated to estimate the risk on DN development. Subgroup analyses based on ethnicity and type of diabetes were also performed. Results: Both the present association study regarding SERPINE1 SNPs (rs2227667, rs2070682, rs1050813, rs2227690, rs2227692) did not found any significant association between SERPINE1 variants and DN and the meta-analysis of variant 4G>5G (rs1799889) did not also reveal a significant association between 4G>5G variant and DN in main and subgroup analyses. Discussion: In conclusion, the present association study and meta-analysis provides strong evidence that SERPINE1 genetic variant $4 \mathrm{G}>5 \mathrm{G}$ is not implicated in the risk or development of DN in Caucasians. Further studies in other populations remain to further investigate the role of this variant in the course of $\mathrm{DN}$.
\end{abstract}

Keywords: SERPINE1; diabetic nephropathy; gene polymorphism; systematic review; meta-analysis

\section{Background}

Diabetic nephropathy (DN) constitutes one of the microvascular complications of both type 1 diabetes mellitus (T1DM) and type 2 diabetes mellitus (T2DM) and the most common form of chronic kidney disease [1]. Despite the glycemic and hemodynamic alterations, the genetic contribution in $\mathrm{DN}$ is unquestionable but still obscure [2,3]. Many genetic loci have been implicated in the pathogenesis of the disease but each genetic loci is characterized of small effect size [4,5].

Two main approaches were used for the genetic dissection of the DN, genetic linkage studies and genetic association studies [6,7]. There is a plethora of genetic linkage stud- 
ies [8-13] and genetic association studies that examines one or more loci or even refers to genome-wide scale [14-20].

Except individual studies, there are also available meta-analyses of these studies. The most recent meta-analysis of genome-wide linkage studies (GWLS) identified significantly suggestive for linkage with DN cytogenetic locations on the following chromosomes: 1q, 3q, $4 p, 5 q, 7 q, 15 q, 16 p, 17 q, 19 q$ and 22p [21]. On the other hand, the most recent meta-analysis of genetic association studies in DN revealed significance of genetic polymorphisms harbored in fifty-one loci and three intergenic regions [22]. In another meta-analysis of genetic association studies, the pathway analysis of significant genes revealed statistically significant overrepresentation of six signalling pathways: cytokine-cytokine receptor interaction, pyruvate metabolism, T2DM, adipocytokine signalling pathway, renal cell carcinoma and the renin-angiotensin system [23].

Among the numerous genetic loci studied in both individual studies [24-31] and metaanalyses [32-34] is serpin family E member 1 (SERPINE1) gene, also known as Plasminogen activator inhibitor-1 (PAI-1), which is a member of the serine proteinase inhibitor (serpin) superfamily and constitutes the principal inhibitor of tissue plasminogen activator (tPA) and urokinase (uPA) leading to inhibition of fibrinolysis [32]. The SERPINE1 gene is located at chromosome band 7q22.1. The protein also functions as a component of innate antiviral immunity. It is known a common polymorphism in the promoter region of the gene, known as 4G/5G (rs1799889), with the 5G allele slightly less transcriptionally active than the 4G allele. Increased PAI-1 levels are associate with diabetic complications [35-37].

In this study, in an effort to enlighten the contribution of SERPINE1 gene in the pathogenesis of DN in the context of T2DM, we selected five tag single-nucleotide polymorphisms (SNPs) for genotyping in a case-control study of Caucasians. In order to confirm the findings of the study, we also performed a meta-analysis of available genetic polymorphisms located in this gene.

\section{Materials and Methods}

\subsection{Association Study}

2.1.1. Study Population

The details about the study design and the participants have been described elsewhere [38]. In brief, a total of 190 patients with DN, 150 T2DM patients without microvascular complications and 238 healthy controls were participated in this study. All participants were examined in the Ophthalmology and Nephrology outpatient clinics of the University Hospital of Larissa in Greece.

The criteria of diabetic nephropathy $(\mathrm{DN})$ was persistent albuminuria, urinary albumin excretion $>300 \mathrm{mg} / 24 \mathrm{~h}(>200 \mu \mathrm{g} / \mathrm{min})$ regardless the elevated or not serum creatinine levels. The study was approved by the University of Thessaly Ethics Committee and informed consent was received from all participants.

\subsubsection{Genotyping}

Genomic DNA was extracted from peripheral blood samples using a salting out method. Based on the HapMap population database for Utah residents with Northern and Western European ancestry (CEU) (Release 27, Phase II+III, Feb09, on NCBI B36 assembly, dbSNP b126) tag single nucleotide polymorphisms (SNPs) across SERPINE1 (spanning a $11.86 \mathrm{kbp}$ region that consists of nine exons in chr7:positions 100,557,172 to $100,569,026)$ were identified on the basis of linkage disequilibrium (LD) blocks according to HapMap project (http:/ / hapmap.ncbi.nlm.nih.gov accessed on 15 May 2016) using the tagger genetic program (http:/ / www.broadinstitute.org/mpg/tagger accessed on 15 May 2016). Selection of tagging SNPs was conducted using criteria of $\mathrm{r}^{2}$ cut-off of greater than or equal to 0.8 and minor allele frequency (MAF) of $>0.05$. The details of the selection of tagging SNPs have been also described elsewhere(38). A total of 5 tag SNPs in four distinct gene regions were retrieved in the intronic region between exons 3-4 (rs2227667), in the intron 5-6 (rs2070682, rs2227690), the intron 7-8 (rs2227692), and in the $3^{\prime} \mathrm{UTR}$ region 
(rs1050813). The captured tag SNPs were distributed in two specific LD blocks: rs2227667 in block 1 and rs2070682, rs2227690, rs2227692, and rs1050813 in block 2.

Genotyping of tag SNPs was performed with a TaqMan allele specific discrimination assays method on an ABI PRISM 7900 sequence detection system and was analyzed with the SDS software version 2.3 (Applied Biosystems, Foster City, CA, USA) [38]. The laboratory personnel was blinded to the clinical status.

\subsubsection{Data Analysis}

The data for continuous variables were expressed as mean value and standard deviation [mean $\pm \mathrm{SD}$ ] and data for nominal variables as count (or ratio) and percentage [n (\%)]. The association between genotype distribution and disease was examined using the generalized odds ratio $\left(\mathrm{OR}_{\mathrm{G}}\right)[39,40]$. In healthy controls, deviation of the genotype distribution from the Hardy-Weinberg equilibrium (HWE) was also tested.

$\mathrm{OR}_{\mathrm{G}}$ was calculated using ORGGASMA (http://biomath.med.uth.gr accessed on 30 August 2021) [39,40]. Statistical analysis was performed with SPSS version 26.0 for Windows (SPSS Inc., Chicago, IL, USA).

\subsection{Meta-Analysis}

\subsubsection{Identification and Eligibility of Relevant Studies}

All of the studies published until December 2020 were identified by extended computer based search of PubMed database. The following search terms were used: ("Serpin family E member 1" or SERPINE1 or "Plasminogen activator inhibitor-1" or PAI-1) AND ("diabetic nephropathy" OR "diabetic kidney disease" OR "end-stage renal disease") AND (genetic or association or gene or polymorphism). We also retrieved articles from genomewide association studies (GWASs) Catalog (https:/ / www.ebi.ac.uk/gwas/ accessed on 1 December 2020). All of the references cited in the included studies were also scrutinized to identify additional published work. Meta-analyses of the included genes were also screened. Case reports, editorials, and review articles were also excluded. The search was restricted to articles in English.

Case-control studies that determined the distribution of genotypes harbored in SERPINE1 gene in cases with DN and in either diseased controls with diabetes but without DN or in healthy controls were eligible for inclusion in the meta-analysis. The inclusion criteria of cases with DN and both diseased controls and healthy controls were the same as those of the present association study. Finally, genome linkage scans were excluded because they regard other study design.

\subsubsection{Data Extraction}

From each article we extracted the following information: first author, year of publication, ethnicity, PubMed unique identifier, type of diabetes and phenotype. For cases and controls, we recorded their number, the selection criteria and the implementation of matching criteria. With regard to genotypic data, we extracted the full genotype counts or allele frequencies.

\subsubsection{Data Synthesis and Analysis}

The association between genotype distribution and disease progression was examined using the generalized odds ratio $\left(\mathrm{OR}_{\mathrm{G}}\right)[39,40]$. The threshold for meta-analysis was the presence of two studies per genetic variant. The pooled OR was estimated using the DerSimonian and Laird [41] random effects model. The associations are presented with ORs generalized for genotypic data with corresponding $95 \%$ confidence intervals (CIs). The between-study heterogeneity was tested with Cochran's $Q$ statistic (considered statistically significant at $p<0.10$ ) [42] and we assessed its extent with the $\mathrm{I}^{2}$ statistic [43]. $\mathrm{OR}_{\mathrm{G}}$ was calculated using a software for implementing the generalized odds ratio methodology for the analysis and meta-analysis of GAS (ORGGASMA) (http:/ /biomath.med.uth.gr accessed on 30 August 2021). 
For each study, we examined whether controls confronted with Hardy-Weinberg equilibrium (HWE) predicted genotypes using Fisher's exact test. For studies providing only allele counts, we relied on the authors' assessment of deviations from HWE. We also tested for small-study effects with the Egger test [44].

\section{Results}

\subsection{Association Study}

The cohort consisted of 190 cases (patients with T2DM and DN), 150 diseased controls (patients with T2DM without DN) and 238 healthy controls. All patients were Caucasians of Greek origin. The demographic and clinical characteristics are shown in Table 1. Among 190 cases with DN 11 were diagnosed with end-stage renal disease (ESRD). The patients were under treatment for chronic kidney disease, diabetes and hypertension including angiotensin-converting enzyme (ACE) inhibitors and angiotensin receptor blockers (ARB) as needed.

Table 1. Clinical characteristics of the participants in the association study.

\begin{tabular}{|c|c|c|c|c|c|c|}
\hline \multirow{2}{*}{ Parameters } & \multicolumn{6}{|c|}{ Case-Control Study Population Groups $(n=578)$} \\
\hline & $\mathrm{HC}$ & DM & $p$ Value & DM-DN & $\mathrm{DM}+\mathrm{DN}$ & $p$ Value \\
\hline$N$ & 238 & 340 & n.a. & 150 & 190 & n.a. \\
\hline Gender $[\mathrm{m} ; n(\%)]$ & $136(42.9)$ & $181(57.1)$ & 0.361 & $74(47.7)$ & $107(54.3)$ & 0.305 \\
\hline Age (years) & $71 \pm 9.2$ & $68 \pm 8.9$ & $<.001$ & $68 \pm 9.1$ & $69 \pm 8.8$ & 0.380 \\
\hline DM duration (years) & n.a. & $16.3 \pm 8.0$ & n.a. & $15.7 \pm 8.3$ & $16.8 \pm 7.8$ & 0.203 \\
\hline $\mathrm{HbA} 1 \mathrm{c}$ & n.d. & $7.36 \pm 1.32$ & n.a. & $7.20 \pm 1.34$ & $7.47 \pm 1.29$ & 0.064 \\
\hline Insulin treatment $(\%)$ & n.d. & $105(32.3)$ & n.a. & $50(32.3)$ & $55(27.9)$ & 0.412 \\
\hline Hypertension (\%) & 0 & $222(63.4)$ & $<.001$ & $97(63.0)$ & $125(63.8)$ & 0.912 \\
\hline Cardiovascular disease $(\%)$ & 0 & $110(31.3)$ & $<.001$ & $41(26.5)$ & $69(35.0)$ & 0.105 \\
\hline Creatinine $(\mathrm{mg} / \mathrm{dL})$ & $0.77 \pm 0.15$ & $1.46 \pm 1.37$ & $<.001$ & $0.90 \pm 0.18$ & $1.85 \pm 1.67$ & $<0.001$ \\
\hline Urea $(\mathrm{mg} / \mathrm{dL})$ & $30 \pm 7.9$ & $59 \pm 34$ & $<.001$ & $42 \pm 13.6$ & $71 \pm 38.3$ & $<0.001$ \\
\hline UACR & $36.7 \pm 63.5$ & $470 \pm 856$ & 0.382 & $43.9 \pm 53.4$ & $783 \pm 1020$ & $<0.001$ \\
\hline Proteinuria (mg/dL) & $136.6 \pm 118.5$ & $788 \pm 1468$ & 0.444 & $105 \pm 80.0$ & $1311 \pm 1784$ & $<0.001$ \\
\hline
\end{tabular}

The genotype distributions of the five variants (rs2227667, rs2070682, rs1050813, rs2227690, rs2227692) in cases, diseased controls and healthy controls, and the respective $\mathrm{OR}_{\mathrm{G}}$, are shown in Table 2 . The healthy controls were conformed to HWE for all variants $(p \geq 0.05)$. There was no significant association in any polymorphism $(p \geq 0.05)$. We also examined the association between the five variants and disease progression taking into account all possible comparisons (Supplementary Tables S1-S5).

In addition, we examined the correlation between individual genotypes and clinical features (Table 3). Only rs2227692 variant was significantly correlated with creatinine levels $(p$-value $=0.037)$. Estimated glomerular filtration rate $(\mathrm{eGFR})$ was also differed statistically significant between healthy controls, diseased controls and diabetic nephropathy cases $(p$-value $<0.001)$. 
Table 2. Genotype frequencies of the participants and results of the association study.

\begin{tabular}{|c|c|c|c|c|c|}
\hline \multirow[t]{2}{*}{ Variant } & \multirow[t]{2}{*}{ Genotype } & \multicolumn{3}{|c|}{ DN } & \multirow[t]{2}{*}{$\mathrm{OR}_{\mathrm{G}}(95 \% \mathrm{CI})$} \\
\hline & & Healthy & Diseased Controls & Cases & \\
\hline \multirow[t]{3}{*}{ rs2227667 } & $\mathrm{AA}$ & 110 & 72 & 100 & \\
\hline & GA & 106 & 63 & 69 & $0.85(0.66,1.08)$ \\
\hline & GG & 18 & 14 & 14 & \\
\hline \multirow[t]{3}{*}{ rs2070682 } & $\mathrm{TT}$ & 81 & 51 & 74 & \\
\hline & TC & 126 & 71 & 83 & $0.97(0.77,1.23)$ \\
\hline & $\mathrm{CC}$ & 30 & 25 & 32 & \\
\hline \multirow[t]{3}{*}{ rs1050813 } & GG & 158 & 113 & 129 & \\
\hline & AG & 67 & 31 & 50 & $0.92(0.69,1.23)$ \\
\hline & AA & 8 & 5 & 6 & \\
\hline \multirow[t]{3}{*}{ rs2227690 } & $\mathrm{AA}$ & 153 & 93 & 132 & \\
\hline & GA & 77 & 44 & 52 & $0.87(0.66,1.15)$ \\
\hline & GG & 6 & 7 & 5 & \\
\hline \multirow[t]{3}{*}{ rs2227692 } & $\mathrm{CC}$ & 184 & 119 & 153 & \\
\hline & $\mathrm{CT}$ & 52 & 30 & 33 & $0.88(0.64,1.23)$ \\
\hline & $\mathrm{TT}$ & 2 & 1 & 4 & \\
\hline
\end{tabular}

Table 3. Correlation of clinical features with individual genotypes.

\begin{tabular}{cccccc}
\hline Clinical Features & \multicolumn{5}{c}{$p$-Value } \\
\hline & rs2227667 & rs2070682 & rs1050813 & rs2227690 & rs2227692 \\
\hline DM duration & 0.806 & 0.178 & 0.806 & 0.299 & 0.619 \\
\hline HbA1c & 0.357 & 0.720 & 0.751 & 0.264 & 0.704 \\
\hline Insulin & 0.522 & 0.223 & 0.927 & 0.871 & 0.712 \\
\hline Hypertension & 0.644 & 0.144 & 0.849 & 0.392 & 0.826 \\
\hline CVD & 0.644 & 0.334 & 0.945 & 0.464 & 0.788 \\
\hline Creatinine & 0.500 & 0.199 & 0.491 & 0.480 & 0.037 \\
\hline Urea & 0.498 & 0.674 & 0.138 & 0.290 & 0.687 \\
\hline UACR & 0.306 & 0.688 & 0.328 & 0.833 & 0.609 \\
\hline Proteinuria & 0.574 & 0.905 & 0.217 & 0.592 & 0.859 \\
\hline eGFR & 0.195 & 0.970 & 0.088 & 0.310 & 0.609 \\
\hline
\end{tabular}

\subsection{Meta-Analysis}

The literature review identified 240 titles in PubMed that met the inclusion criteria. When an article provided data for different populations, each population was considered as a different study. Figure 1 presents a flowchart of retrieved and excluded articles with specifications of reasons for exclusion. The characteristics of each study are shown in Table 4. Across all available studies, only one polymorphism, 4G>5G (rs1799889), was examined in the context of genetic association studies regarding DN and so meta-analyzed. Statistical significance of rs1799889 was not reported in any analysis (Table 5). The studies comprised 1015 cases, 1001 diseased controls and 659 healthy controls and they were published between 1998 and 2016. Figures 2-4 are forest plot representations of variant rs1799889. 


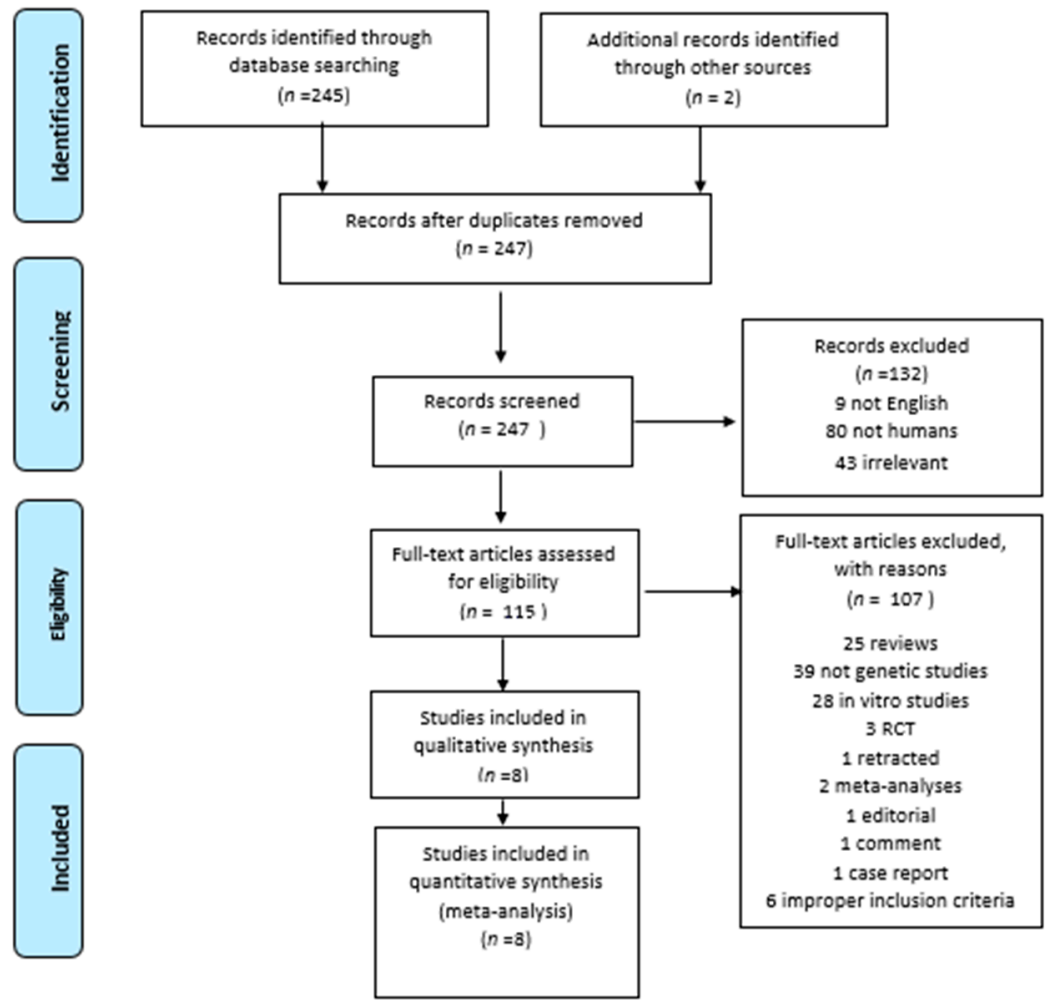

Figure 1. Flowchart of retrieved studies with reasons of exclusion.

\section{Forest plot}

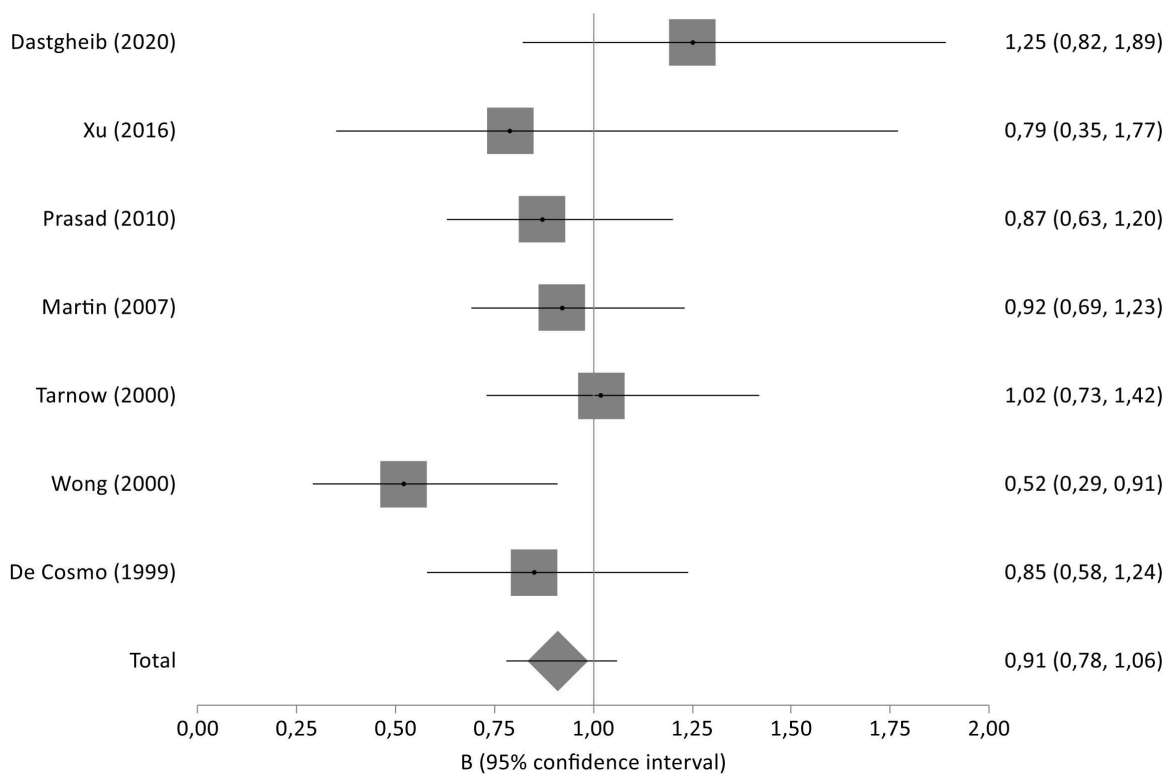

Figure 2. Forest plot of SERPINE1 4G/5G variant between diseased controls versus cases in main meta-analysis. 


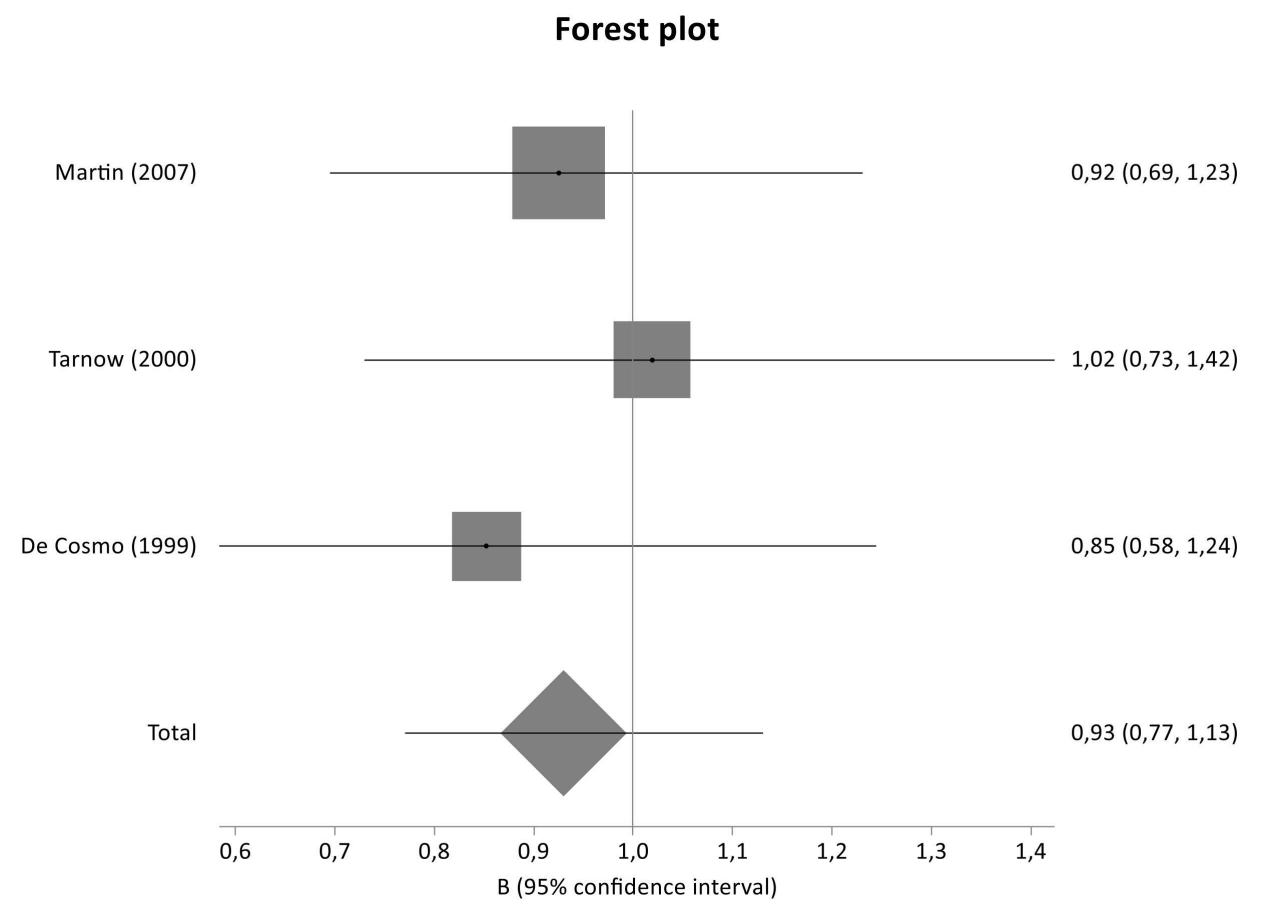

Figure 3. Forest plot of SERPINE1 4G/5G variant between diseased controls versus cases in T1DM subgroup meta-analysis.

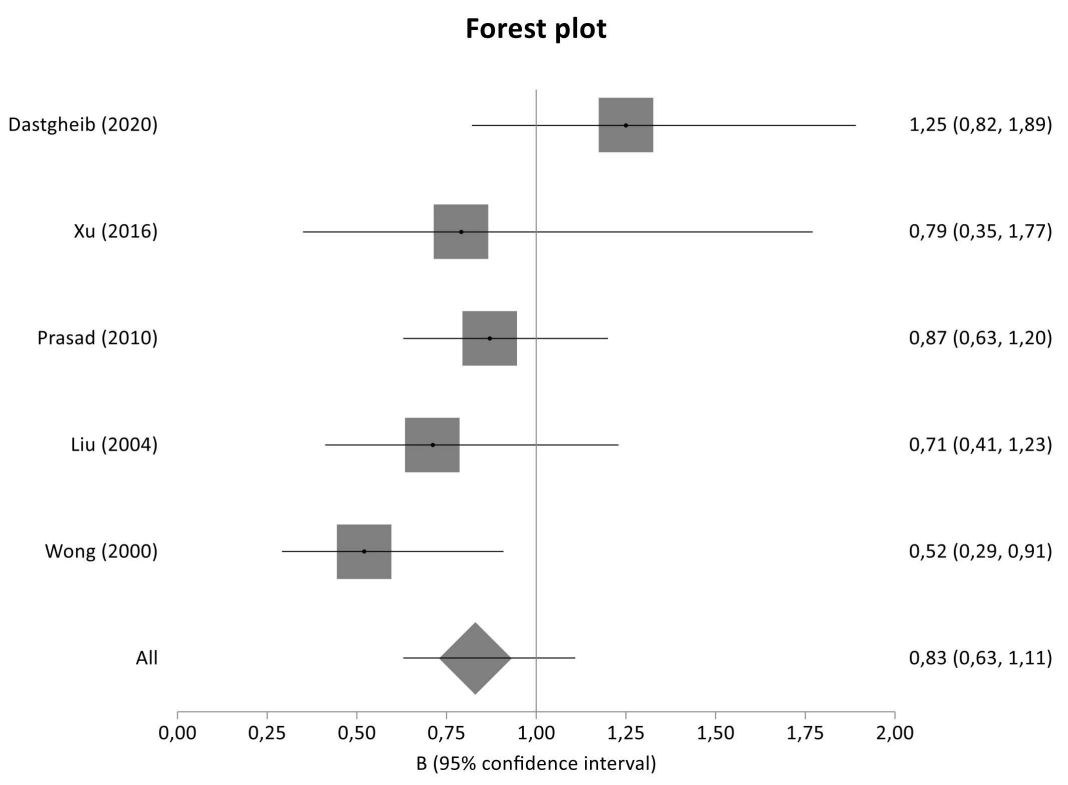

Figure 4. Forest plot of SERPINE1 4G/5G variant between diseased controls versus cases in T2DM subgroup meta-analysis. 
Table 4. Demographic characteristics of the participants of the included studies in the meta-analysis.

\begin{tabular}{|c|c|c|c|c|c|c|c|c|c|c|c|c|c|}
\hline \multirow[t]{7}{*}{$\begin{array}{l}\text { SERPINE1 } \\
\text { rs1799768 }\end{array}$} & $\begin{array}{l}\text { Dastgheib } \\
\text { (2020) [34] }\end{array}$ & E. Asians & 33520873 & T2DM & $\mathrm{DN}$ & 118 & macr/ria & 120 & $\begin{array}{l}\text { norm } / \text { ria without } \\
\text { diabetic retinopathy }\end{array}$ & & & & DC-C \\
\hline & $\mathrm{Xu}(2016)$ [31] & E. Asians & 26616527 & T2DM & DN & 33 & $\mathrm{macr} / \mathrm{ria}$ & 44 & norm/ria & & & & $\begin{array}{c}\text { DC-C, } \\
\text { HT-DC-C, } \\
\text { HT-C } \\
\end{array}$ \\
\hline & $\begin{array}{l}\text { Martin (2007) } \\
\quad[29]\end{array}$ & Caucasians & 17263760 & T1DM & DN & 222 & $\begin{array}{l}\mathrm{DM} \geq 10 \text { yrs, pers. } \\
\text { proteinuria, } \mathrm{DR}, \mathrm{no} \\
\text { evidence of } \\
\text { non-diabetic renal } \\
\text { disease } \\
\end{array}$ & 361 & $\begin{array}{l}\mathrm{DM}>15 \text { yrs, pers. } \\
\text { norm/ria, no anti-HT } \\
\text { meds, background DR }\end{array}$ & 86 & non-diabetics & & $\begin{array}{c}\text { DC-C, } \\
\text { HT-DC-C, } \\
\text { HT-C }\end{array}$ \\
\hline & $\begin{array}{l}\text { Tarnow } \\
(2000)[26]\end{array}$ & Caucasians & 10809802 & T1DM & DN & 198 & $\begin{array}{l}\text { diabetic } \\
\text { glomerulosclerosis, } \\
\text { pers. macr/ria, } \\
\text { retinopathy }\end{array}$ & 192 & $\begin{array}{l}\text { pers. norm/ria age, } \\
\text { gender, DM duration }\end{array}$ & & & No & DC-C \\
\hline & $\begin{array}{l}\text { Wong (2000) } \\
{[27]}\end{array}$ & E. Asians & 10652041 & $\mathrm{~T} 2 \mathrm{DM}$ & DN & 95 & $\begin{array}{l}\text { pers. mi- } \\
\text { cro/macroalbuminuriaor } \\
\text { dialysis }\end{array}$ & 46 & $\begin{array}{c}\text { pers. norm } / \text { ria, } \mathrm{DM} \\
\text { duration }>12 \text { yrs } \\
\text { matched for age, gender }\end{array}$ & & & No & $\begin{array}{c}\text { DC-C, } \\
\text { HT-DC-C, } \\
\text { HT-C }\end{array}$ \\
\hline & $\begin{array}{l}\text { De Cosmo } \\
\text { (1999) [25] }\end{array}$ & Caucasians & 10495473 & T1DM & $\mathrm{DN}$ & 175 & $\begin{array}{l}\text { micro/macroalbuminuria, } \\
\text { retinopathy }\end{array}$ & 136 & norm/ria, DM > 15 yrs & 200 & non-diabetics & & $\begin{array}{c}\text { DC-C, } \\
\text { HT-DC-C, } \\
\text { HT-C }\end{array}$ \\
\hline & $\begin{array}{l}\text { Kimura } \\
(1998)[24]\end{array}$ & E. Asians & 9844142 & $\mathrm{~T} 2 \mathrm{DM}$ & DN & 98 & $\begin{array}{l}\text { overt proteinuria, } \\
\text { impaired renal } \\
\text { function, DR or ESRD } \\
\text { requiring dialysis }\end{array}$ & & - & 177 & non-diabetics & & HT-C \\
\hline
\end{tabular}


Table 5. Statistically significant results from meta-analysis of $4 \mathrm{G} / 5 \mathrm{G}$ polymorphism.

\begin{tabular}{|c|c|c|c|c|c|c|c|c|c|c|}
\hline \multicolumn{11}{|c|}{ Diseased Controls versus Cases } \\
\hline Gene & Polymorphism & $\begin{array}{c}\text { Rs } \\
\text { number }\end{array}$ & $\mathrm{N}$ & \multicolumn{2}{|c|}{ Cases/ControlßE OR $\mathrm{G}_{\mathrm{G}}$} & $\mathrm{LL} \mathrm{OR}_{\mathrm{G}}$ & $\mathrm{UL} \mathrm{OR}_{\mathrm{G}}$ & $\mathrm{I}^{2}$ & $\mathrm{P}_{\mathrm{Q}}$ & $P_{E}$ \\
\hline SERPINE1 & $\begin{array}{l}\text { c. }-821 \_-820 \text { insG } \\
(4 G>5 G)\end{array}$ & rs1799768 & 7 & $1035 / 1121$ & 0.91 & 0.78 & 1.06 & 6.76 & 0.34 & 0.13 \\
\hline SERPINE1 & All in HWE & & 4 & $626 / 764$ & 0.88 & 0.74 & 1.06 & 0 & 0.98 & 0.17 \\
\hline \multicolumn{11}{|c|}{ T1DM/Caucasians } \\
\hline SERPINE1 & $4 G>5 G$ & rs1799768 & 3 & $594 / 688$ & 0.93 & 0.77 & 1.13 & 0 & 0.78 & 0.08 \\
\hline \multicolumn{11}{|c|}{ T2DM/Asians } \\
\hline SERPINE1 & $4 G>5 G$ & rs1799768 & 4 & $518 / 503$ & 0.85 & 0.60 & 1.21 & 51.08 & 0.11 & 0.15 \\
\hline SERPINE1 & $4 G>5 G$ & rs1799768 & 2 & $400 / 383$ & 0.86 & 0.64 & 1.16 & 0 & 0.83 & 0.12 \\
\hline \multicolumn{11}{|c|}{ Healthy Controls versus Diseased Controls versus Cases } \\
\hline SERPINE1 & $\begin{array}{l}\text { c. }-821 \_-820 \text { insG } \\
(4 G>5 G)\end{array}$ & rs1799768 & 4 & & 0.9 & 0.76 & 1.05 & 14.57 & 0.32 & 0 \\
\hline \multicolumn{11}{|c|}{ T1DM/Caucasians } \\
\hline SERPINE1 & & & 2 & & 0.96 & 0.81 & 1.14 & 0 & 0.83 & - \\
\hline \multicolumn{11}{|c|}{ T2DM/Asians } \\
\hline SERPINE1 & & & 2 & & 0.74 & 0.53 & 1.04 & & & - \\
\hline \multicolumn{11}{|c|}{ Healthy Controls versus Cases } \\
\hline SERPINE1 & $\begin{array}{c}\text { c.-821_-820insG } \\
(4 G>5 G)\end{array}$ & rs1799768 & 5 & $622 / 659$ & 0.92 & 0.74 & 1.13 & 9.02 & 0.36 & 0.07 \\
\hline \multicolumn{11}{|c|}{ T1DM/Caucasians } \\
\hline SERPINE1 & $\begin{array}{c}\text { c. }-821 \_-820 \text { insG } \\
(4 G>5 G)\end{array}$ & rs1799768 & 2 & & 0.96 & 0.73 & 1.25 & 0 & 0.70 & - \\
\hline \multicolumn{11}{|c|}{ T2DM/Asians } \\
\hline SERPINE1 & $\begin{array}{l}\text { c. }-821 \_-820 \text { insG } \\
(4 G>5 G)\end{array}$ & rs1799768 & 3 & & 0.83 & 0.55 & 1.27 & 50.87 & 0.13 & - \\
\hline
\end{tabular}

\section{Discussion}

In an effort to provide the most comprehensive overview assessing for genetic variation in SERPINE1 gene, we selected five tag SNPs for genotyping in a cohort of Greek origin and we also performed a meta-analysis that included all available genetic data regarding genetic variants of the aforementioned gene.

SERPINE1 gene polymorphisms have been studied in various systematic reviews and meta-analyses regarding atherosclerotic diseases [45], risk of venous thromboembolism [46], stroke susceptibility [47] and diabetic nephropathy [32,38,48].

The present association study did not reveal statistical significance for any genotyped tag SNP located in SERPINE1 gene. Similarly, the overall meta-analysis of $4 \mathrm{G}>5 \mathrm{G}$ variant (rs1799889) as well as the subgroup analyses based on diabetes type and ethnicity did not detect any significant association, indicating no implication of SERPINE1 variants in the risk or development of the disease.

In agreement to the findings of the present genetic association study and meta-analysis, De Cosmo et al. (1999) found no association between SERPINE1 4G/5G polymorphism and DN in Europeans patients with T1DM [45]. Similarly, one more study in Caucasians with T1DM did not detect any significant association between twenty-one polymorphisms of SERPINE1 and DN [29].

In contrast to our findings, Dastgheib et al. (2020) found that the PAI-1 4G5G polymorphism was associated with increased risk of DN and diabetic retinopathy (DR) risk [34]. Furthermore, Wong et al. (2000) concluded that SERPINE1 4G/4G is an independent factor 
for the development of DN in Chinese patients with T2DM and also exhibits a synergistic effect with the allele D of $A C E$ gene on development of DN [27]. In addition, meta-analysis of Xue et al. (2014) reported a significant association between 4G/4G genotype and the risk of developing DN in overall analysis but also in both Asians and T2DM patients with DN [32]. Last but not least, one more meta-analysis showed that the SERPINE1 4G allele might be risk allele for DN susceptibility in the Chinese population [48].

Taking into account the discrepancy in findings derived from different study, it could be suggested that genetic variability in SERPINE1 is influenced by the ethnicity and/or type of diabetes, as many studies conducted in Asians with T2DM detected significant association between genetic variants of SERPINE1 and DN, whereas studies performed in Caucasians with T1DM did not detect any significant association between SERPINE1 and DN. Our suggestion is in agreement with the conclusion of a recent meta-analysis of SERPINE1 rs1799889 variant, in which Chen et al. (2021) concluded that 4G polymorphism could constitute a genetic synergistic factor in overall DM and DN populations, positively for individuals with Asian descent [49]. It is noteworthy to be mentioned that the association of rs1799889 variant was not revealed significant in diabetic retinopathy and cardiovascular risks [49].

Our study design has several strengths out of which clear case definition is one of them. Patients without persistent proteinuria were not considered as cases with DN, since not persistent proteinuria could be reversible and could lead to underestimation of the genetic effect. In addition, we included in the study, healthy controls without diabetes in order to discriminate any variant correlated with diabetes mellitus but not with DN per se. Moreover, the use of $\mathrm{OR}_{\mathrm{G}}$ is a model-free approach, so it takes advantage of the full genotype distribution and provides a straightforward interpretation of genetic associations. On the other hand, the present study has certain limitations. The sample size of the present case-control study is relatively small raising the possibility of false positive and false negative results, an inherent though limitation of the majority of genetic association studies. Moreover, in the present meta-analysis only studies written in English language were included.

\section{Conclusions}

In conclusion, we investigated the role of SERPINE1 gene polymorphisms in the context of a case-control study without statistical significant results for any variant. In an effort to further examine the role of SERPINE1 gene variants in the risk of DN, we performed a systematic review and meta-analysis where $4 \mathrm{G} / 5 \mathrm{G}$ polymorphism was also not revealed statistical significant. Further studies remain to verify the results of the present meta-analysis.

Supplementary Materials: The following are available online at https://www.mdpi.com/article/ 10.3390/genes12121887/s1, Table S1: Genotype frequencies of the participants and results of the association study between healthy controls versus diabetics (with and without diabetic nephropathy), Table S2: Genotype frequencies of the participants and results of the association study between cases versus controls (with and without diabetes), Table S3: Genotype frequencies of the participants and results of the association study between healthy and diseased controls, Table S4: Genotype frequencies of the participants and results of the association study between healthy controls versus cases with diabetic nephropathy, Table S5: Genotype frequencies of the participants and results of the association study between diseased controls versus cases with diabetic nephropathy.

Author Contributions: I.S., G.M.H. and E.T. designed the research, E.D., G.F., S.G., V.S., T.E. and S.V.T. recruited the patients, G.P. conducted the genotyping assays and M.T. performed the statistical analysis and drafted the paper. All authors have read and agreed to the published version of the manuscript.

Funding: This manuscript has received no external funding.

Institutional Review Board Statement: The study was approved by the University of Thessaly Ethics Committee and informed consent was received from all participants. 
Informed Consent Statement: Informed consent was obtained from all subjects involved in the study.

Data Availability Statement: The datasets used and/or analysed during the current study are available from the corresponding author on reasonable request.

Conflicts of Interest: The authors declare that they have no competing interests.

$\begin{array}{ll}\text { Abbreviations } \\ \text { DN } & \text { diabetic nephropathy; } \\ \text { GWASs } & \text { Genome-Wide Association Studies; } \\ \text { GWLS } & \text { Genome-Wide Linkage Studies; } \\ \text { HWE } & \text { Hardy-Weinberg equilibrium; } \\ \text { MAF } & \text { Minor Allele Frequency; } \\ \text { OR }_{\mathrm{G}} & \text { Generalized Odds Ratio; } \\ \text { PAI-1 } & \text { Plasminogen activator inhibitor-1; } \\ \text { serpin } & \text { serine proteinase inhibitor; } \\ \text { SERPINE1 } & \text { serpin family E member 1; } \\ \text { SNPs } & \text { Single-Nucleotide Polymorphisms; } \\ \text { T1DM } & \text { type 1 diabetes mellitus; } \\ \text { T2DM } & \text { type 2 diabetes mellitus; } \\ \text { tPA } & \text { tissue plasminogen activator; } \\ \text { uPA } & \text { urokinase. }\end{array}$

\section{References}

1. Cowie, C.C.; Port, F.K.; Wolfe, R.A.; Savage, P.J.; Moll, P.P.; Hawthorne, V.M. Disparities in incidence of diabetic end-stage renal disease according to race and type of diabetes. N. Engl. J. Med. 1989, 321, 1074-1079. [CrossRef] [PubMed]

2. Dronavalli, S.; Duka, I.; Bakris, G. The pathogenesis of diabetic nephropathy. Nat. Clin. Pract. Endocrinol. Metab. 2008, 4, 444-452. Available online: http:/ / www.ncbi.nlm.nih.gov/pubmed/18607402 (accessed on 23 November 2021). [CrossRef] [PubMed]

3. Thomas, M.C.; Brownlee, M.; Susztak, K.; Sharma, K.; Jandeleit-Dahm, K.A.M.; Zoungas, S.; Rossing, P.; Groop, P.-H.; Cooper, M.E. Diabetic kidney disease. Nat. Rev. Dis. Primers 2015, 1, 15070. Available online: http://www.nature.com/articles/nrdp201570 (accessed on 23 November 2021). [CrossRef]

4. Thomas, M.; Groop, P.-H.; Tryggvason, K. Towards understanding the inherited susceptibility for nephropathy in diabetes. Curr. Opin. Nephrol. Hypertens. 2012, 21, 195-202. [CrossRef]

5. Cole, J.B.; Florez, J.C. Genetics of diabetes mellitus and diabetes complications. Nat. Rev. Nephrol. 2020, 16, 377-390. [CrossRef]

6. Lander, E.; Kruglyak, L. Genetic dissection of complex traits: Guidelines for interpreting and reporting linkage results. Nat. Genet. 1995, 11, 241-247. [CrossRef]

7. Cordell, H.J.; Clayton, D.G. Genetic association studies. Lancet 2005, 366, 1121-1131. Available online: http:/ / www.sciencedirect. com/science/article/pii/S0140673605674247 (accessed on 23 November 2021). [CrossRef]

8. Iyengar, S.K.; Abboud, H.E.; Goddard, K.A.B.; Saad, M.F.; Adler, S.G.; Arar, N.H.; Bowden, D.W.; Duggirala, R.; Elston, R.C.; Hanson, R.L.; et al. Genome-Wide Scans for Diabetic Nephropathy and Albuminuria in Multiethnic Populations. Diabetes 2007, 56, 1577-1585. [CrossRef]

9. Krolewski, A.S.; Poznik, G.D.; Placha, G.; Canani, L.; Dunn, J.; Walker, W.; Smiles, A.; Krolewski, B.; Fogarty, D.G.; Moczulski, D.; et al. A genome-wide linkage scan for genes controlling variation in urinary albumin excretion in type II diabetes. Kidney Int. 2006, 69, 129-136. Available online: http://www.ncbi.nlm.nih.gov/pubmed/16374433 (accessed on 23 November 2021). [CrossRef]

10. Osterholm, A.-M.; He, B.; Pitkaniemi, J.; Albinsson, L.; Berg, T.; Sarti, C.; Tuomilehto, J.; Tryggvason, K. Genome-wide scan for type 1 diabetic nephropathy in the Finnish population reveals suggestive linkage to a single locus on chromosome 3q. Kidney Int. 2007, 71, 140-145. Available online: http:/ /www.ncbi.nlm.nih.gov/pubmed/17021601 (accessed on 23 November 2021). [CrossRef]

11. Rogus, J.J.; Poznik, G.D.; Pezzolesi, M.G.; Smiles, A.M.; Dunn, J.; Walker, W.; Wanic, K.; Moczulski, D.; Canani, L.; Araki, S.; et al. High-Density Single Nucleotide Polymorphism Genome-Wide Linkage Scan for Susceptibility Genes for Diabetic Nephropathy in Type 1 Diabetes Discordant Sibpair Approach. Diabetes 2008, 57, 2519-2526. [CrossRef]

12. Wessman, M.; Forsblom, C.; Kaunisto, M.A.; Söderlund, J.; Ilonen, J.; Sallinen, R.; Hiekkalinna, T.; Parkkonen, M.; Maxwell, A.P.; Tarnow, L.; et al. Novel susceptibility locus at 22q11 for diabetic nephropathy in type 1 diabetes. PLoS ONE 2011, 6, e24053. Available online: http:/ / www.pubmedcentral.nih.gov / articlerender.fcgi?artid=3164698\&tool=pmcentrez\&rendertype=abstract (accessed on 23 November 2021). [CrossRef] 
13. Igo, R.P.; Iyengar, S.K.; Nicholas, S.B.; Goddard, K.a.B.; Langefeld, C.D.; Hanson, R.L.; Duggirala, R.; Divers, J.; Abboud, H.; Adler, S.G.; et al. Genomewide linkage scan for diabetic renal failure and albuminuria: The FIND study. Am. J. Nephrol. 2011, 33, 381-389. Available online: http: / / www.pubmedcentral.nih.gov / articlerender.fcgi?artid=3078269\&tool=pmcentrez\&rendertype=abstract (accessed on 23 November 2021). [CrossRef]

14. Stefanidis, I.; Tziastoudi, M.; Tsironi, E.E.; Dardiotis, E.; Tachmitzi, S.V.; Fotiadou, A.; Pissas, G.; Kytoudis, K.; Sounidaki, M.; Ampatzis, G.; et al. The contribution of genetic variants of SLC2A1 gene in T2DM and T2DM-nephropathy: Association study and meta-analysis. Ren. Fail. 2018, 40, 561-576. Available online: https://www.tandfonline.com/doi/full/10.1080/0886022X.20 18.1496931 (accessed on 23 November 2021). [CrossRef]

15. Tachmitzi, S.V.; Tsironi, E.E.; Kotoula, M.G.; Dardiotis, E.; Eleftheriadis, T.; Chatzoulis, D.Z.; Xanthopoulou, P.; Tziastoudi, M.; Koutsiaris, A.G.; Fotiadou, A.; et al. Association between Polymorphisms and Haplotypes in AKR1B1 and Diabetes Type 2 leading to Complications. Int. J. Med. Health Sci. 2015, 4, 430-436.

16. Taira, M.; Imamura, M.; Takahashi, A.; Kamatani, Y.; Yamauchi, T.; Araki, S.-I.; Tanaka, N.; van Zuydam, N.R.; Ahlqvist, E.; Toyoda, M.; et al. A variant within the FTO confers susceptibility to diabetic nephropathy in Japanese patients with type 2 diabetes. PLoS ONE 2018, 13, e0208654. [CrossRef]

17. Germain, M.; Pezzolesi, M.G.; Sandholm, N.; McKnight, A.J.; Susztak, K.; Lajer, M.; Forsblom, C.; Marre, M.; Parving, H.-H.; Rossing, P.; et al. SORBS1 gene, a new candidate for diabetic nephropathy: Results from a multi-stage genome-wide association study in patients with type 1 diabetes. Diabetologia 2015, 58, 543-548. [CrossRef]

18. McDonough, C.W.; Palmer, N.D.; Hicks, P.J.; Roh, B.H.; An, S.S.; Cooke, J.N.; Hester, J.M.; Wing, M.R.; Bostrom, M.A.; Rudock, M.E.; et al. A genome-wide association study for diabetic nephropathy genes in African Americans. Kidney Int. 2011, 79, 563-572. [CrossRef]

19. Pezzolesi, M.G.; Poznik, G.D.; Mychaleckyj, J.C.; Paterson, A.D.; Barati, M.T.; Klein, J.B.; Ng, D.P.K.; Placha, G.; Canani, L.H.; Bochenski, J.; et al. Genome-Wide Association Scan for Diabetic Nephropathy Susceptibility Genes in Type 1 Diabetes. Diabetes 2009, 58, 1403-1410. [CrossRef]

20. Maeda, S.; Osawa, N.; Hayashi, T.; Tsukada, S.; Kobayashi, M.; Kikkawa, R. Genetic variations associated with diabetic nephropathy and type II diabetes in a Japanese population. Kidney Int. Suppl. 2007, 72, S43-S48. [CrossRef]

21. Tziastoudi, M.; Stefanidis, I.; Stravodimos, K.; Zintzaras, E. Identification of Chromosomal Regions Linked to Diabetic Nephropathy: A Meta-Analysis of Genome-Wide Linkage Scans. Genet. Test. Mol. Biomark. 2019, 23, 105-117. [CrossRef]

22. Tziastoudi, M.; Stefanidis, I.; Zintzaras, E. The genetic map of diabetic nephropathy: Evidence from a systematic review and meta-analysis of genetic association studies. Clin. Kidney J. 2020, 13, 768-781. [CrossRef]

23. Tziastoudi, M.; Stefanidis, I.; Hadjigeorgiou, G.M.; Stravodimos, K.; Zintzaras, E. A systematic review and meta-analysis of genetic association studies for the role of inflammation and the immune system in diabetic nephropathy. Clin. Kidney J. 2017, 10, 293-300. [CrossRef]

24. Kimura, H.; Gejyo, F.; Suzuki, Y.; Suzuki, S.; Miyazaki, R.; Arakawa, M. Polymorphisms of angiotensin converting enzyme and plasminogen activator inhibitor-1 genes in diabetes and macroangiopathy1. Kidney Int. 1998, 54, 1659-1669. [CrossRef]

25. De Cosmo, S.; Margaglione, M.; Tassi, V.; Garrubba, M.; Thomas, S.; Olivetti, C.; Piras, G.P.; Trevisan, R.; Vedovato, M.; Cavallo Perin, P.; et al. ACE, PAI-1, decorin and Werner helicase genes are not associated with the development of renal disease in European patients with type 1 diabetes. Diabetes Metab. Res. Rev. 1999, 15, 247-253. [CrossRef]

26. Tarnow, L.; Stehouwer, C.D.; Emeis, J.J.; Poirier, O.; Cambien, F.; Hansen, B.V.; Parving, H.-H. Plasminogen activator inhibitor-1 and apolipoprotein E gene polymorphisms and diabetic angiopathy. Nephrol. Dial. Transplant. 2000, 15, 625-630. [CrossRef]

27. Wong, T.Y.; Poon, P.; Szeto, C.C.; Chan, J.C.; Li, P.K. Association of plasminogen activator inhibitor-1 4G/4G genotype and type 2 diabetic nephropathy in Chinese patients. Kidney Int. 2000, 57, 632-638. [CrossRef]

28. Liu, S.; Xue, Y.; Yang, G.; He, F.; Zhao, X. Relationship between plasminogen activator inhibitor-1 gene 4G/5G polymorphism and type 2 diabetic nephropathy in Chinese Han patients in Guangdong Province. Di 1 Jun Yi Da Xue Xue Bao Acad. J. First Med. Coll. PLA 2004, 24, 904-907.

29. Martin, R.J.L.; Savage, D.A.; Patterson, C.C.; Brady, H.R.; Maxwell, A.P. Common polymorphisms of the PAI1 gene do not play a major role in the development of diabetic nephropathy in Type 1 diabetes. Diabet. Med. J. Br. Diabet. Assoc. 2007, 24, 259-265. Available online: http:/ / www.ncbi.nlm.nih.gov/pubmed/17263760 (accessed on 23 November 2021). [CrossRef]

30. Prasad, P.; Tiwari, A.K.; Kumar, K.M.P.; Ammini, A.C.; Gupta, A.; Gupta, R.; Thelma, B.K. Association analysis of ADPRT1, AKR1B1, RAGE, GFPT2 and PAI-1 gene polymorphisms with chronic renal insufficiency among Asian Indians with type-2 diabetes. BMC Med. Genet. 2010, 11, 52. [CrossRef]

31. Xu, F.; Liu, H.; Sun, Y. Association of plasminogen activator inhibitor-1 gene polymorphism and type 2 diabetic nephropathy. Ren Fail. 2016, 38, 157-162. Available online: http://www.tandfonline.com/doi/full/10.3109/0886022X.2015.1089464 (accessed on 23 November 2021). [CrossRef] [PubMed]

32. Xue, C.; Nie, W.; Zhou, C.; Yu, F.; Wang, D.-M.; Dai, B.; Mei, C.-L. 4 G/4 G polymorphism of plasminogen activator inhibitor-1 gene increases the risk of diabetic nephropathy. Ren. Fail. 2014, 36, 332-338. [CrossRef] [PubMed]

33. Xu, K.; Liu, X.; Yang, F.; Cui, D.; Shi, Y.; Shen, C.; Tang, W.; Yang, T. PAI-1-675 4G/5G polymorphism in association with diabetes and diabetic complications susceptibility: A meta-analysis study. PLoS ONE 2013, 8, e79150. 
34. Dastgheib, S.A.; Najafi, F.; Shajari, A.; Bahrami, R.; Asadian, F.; Sadeghizadeh-Yazdi, J.; Akbarian, E.; Emarati, S.A.; Neamatzadeh, H. Association of plasminogen activator inhibitor-1 4G5G Polymorphism with risk of diabetic nephropathy and retinopathy: A systematic review and meta-analysis. J. Diabetes Metab. Disord. 2020, 19, 2005-2016. [CrossRef] [PubMed]

35. Festa, A.; D'Agostino, R.J.; Tracy, R.P.; Haffner, S.M. Elevated levels of acute-phase proteins and plasminogen activator inhibitor-1 predict the development of type 2 diabetes: The insulin resistance atherosclerosis study. Diabetes 2002, 51, 1131-1137. [CrossRef] [PubMed]

36. Gori, A.M.; Marcucci, R.; Fatini, C.; Gensini, F.; Sticchi, E.; Sodi, A.; Cappelli, S.; Menchini, U.; Gensini, G.F.; Abbate, R.; et al. Impaired fibrinolysis in retinal vein occlusion: A role for genetic determinants of PAI-1 levels. Thromb. Haemost. 2004, 92, 54-60. [PubMed]

37. Steinberger, J.; Daniels, S.R. Obesity, insulin resistance, diabetes, and cardiovascular risk in children: An American Heart Association scientific statement from the Atherosclerosis, Hypertension, and Obesity in the Young Committee (Council on Cardiovascular Disease in the Young) and the Diabetes Committee (Council on Nutrition, Physical Activity, and Metabolism). Circulation 2003, 107, 1448-1453.

38. Siokas, V.; Dardiotis, E.; Sokolakis, T.; Kotoula, M.; Tachmitzi, S.V.; Chatzoulis, D.Z.; Almpanidou, P.; Stefanidis, I.; Hadjigeorgiou, G.M.; Tsironi, E.E. Plasminogen Activator Inhibitor Type-1 Tag Single-Nucleotide Polymorphisms in Patients with Diabetes Mellitus Type 2 and Diabetic Retinopathy. Curr. Eye Res. 2017, 42, 1048-1053. [CrossRef]

39. Zintzaras, E. The generalized odds ratio as a measure of genetic risk effect in the analysis and meta-analysis of association studies. Stat. Appl. Genet. Mol. Biol. 2010, 9, 21. Available online: http://www.ncbi.nlm.nih.gov/pubmed/20597847 (accessed on 23 November 2021). [CrossRef]

40. Zintzaras, E. The power of generalized odds ratio in assessing association in genetic studies. J. Appl. Stat. 2012, 39, 2569-2581. [CrossRef]

41. DerSimonian, R.; Laird, N. Meta-analysis in clinical trials. Control. Clin. Trials. 1986, 7, 177-188. Available online: http: / / www.ncbi.nlm.nih.gov/pubmed/3802833 (accessed on 23 November 2021). [CrossRef]

42. Cochran, W. The combination of estimates from different experiments. Biometrics 1954, 10, 101-129. Available online: http: //www.jstor.org/stable/3001666 (accessed on 23 November 2021). [CrossRef]

43. Higgins, J.P.T.; Thompson, S.G. Quantifying heterogeneity in a meta-analysis. Stat. Med. 2002, 21, 1539-1558. Available online: http:/ / www.ncbi.nlm.nih.gov/pubmed/12111919 (accessed on 23 November 2021). [CrossRef]

44. Egger, M.; Davey Smith, G.; Schneider, M.; Minder, C. Bias in meta-analysis detected by a simple, graphical test. Br. Med. J. 1997, 315, 629-634. Available online: http://www.ncbi.nlm.nih.gov/pubmed/9310563 (accessed on 23 November 2021). [CrossRef]

45. Liu, Y.; Cheng, J.; Guo, X.; Mo, J.; Gao, B.; Zhou, H.; Wu, Y.; Li, Z. The roles of PAI-1 gene polymorphisms in atherosclerotic diseases: A systematic review and meta-analysis involving 149,908 subjects. Gene 2018, 673, 167-173. [CrossRef]

46. Zhang, Q.; Jin, Y.; Li, X.; Peng, X.; Peng, N.; Song, J.; Xu, M. Plasminogen activator inhibitor-1 (PAI-1) 4G/5G promoter polymorphisms and risk of venous thromboembolism-A meta-analysis and systematic review. VASA Z. Gefasskrankh. 2020, 49, 141-146. [CrossRef]

47. Hu, X.; Zan, X.; Xie, Z.; Li, Y.; Lin, S.; Li, H.; You, C. Association Between Plasminogen Activator Inhibitor-1 Genetic Polymorphisms and Stroke Susceptibility. Mol. Neurobiol. 2017, 54, 328-341. [CrossRef]

48. Gao, W.-F.; Guo, Y.-B.; Bai, Y.; Ding, X.-Y.; Yan, Y.-J.; Wu, Z.-Q. Association between PAI-1 4G/5G polymorphism and diabetic nephropathy: A meta-analysis in the Chinese population. Int. Urol. Nephrol. 2016, 48, 1483-1489. [CrossRef]

49. Chen, J.; Zhai, C.; Wang, Z.; Li, R.; Wu, W.; Hou, K.; Alzogool, M.; Wang, Y.; Cong, H. The susceptibility of SERPINE1 rs1799889 SNP in diabetic vascular complications: A meta-analysis of fifty-one case-control studies. BMC Endocr. Disord. 2021, 21, 195. [CrossRef] 